\title{
Investigation of Blade Number Effect on Hydraulic Performance of In-Pipe Hydro Savonius Turbine
}

\author{
S. Abdolkarim Payambarpour, ${ }^{1}$ Amir F. Najafi ${ }^{(D)}{ }^{1}$ and Franco Magagnato ${ }^{2}$ \\ ${ }^{1}$ Hydraulic Machinery Research Institute, School of Mechanical Engineering, College of Engineering, University of Tehran, \\ P.O. Box 11365/4563, Tehran, Iran \\ ${ }^{2}$ Institute of Fluid Mechanics, Karlsruhe Institute of Technology, 76131 Karlsruhe, Germany
}

Correspondence should be addressed to Amir F. Najafi; afnajafi@ut.ac.ir

Received 28 March 2019; Revised 28 May 2019; Accepted 16 June 2019; Published 22 July 2019

Academic Editor: Ryoichi Samuel Amano

\begin{abstract}
Copyright ( 2019 S. Abdolkarim Payambarpour et al. This is an open access article distributed under the Creative Commons Attribution License, which permits unrestricted use, distribution, and reproduction in any medium, provided the original work is properly cited.
\end{abstract}

Level of utilization of clean energy has grown dramatically in recent years due to increased pollution and environmental issues. For instance, the extra potential energy in water supply system is usually wasted, due to its low capacity. Design of a proper turbine has recently been given more attention by researchers to apply this clean energy. In the present paper, a modified Savonius turbine, suitable for use in a 4-inch pipe, is designed. Turbine with two blades is tested in a laboratory rig and also simulated with the FLUENT software. By matching numerical and laboratory results, simulations are expanded and the blades number effect on turbine performance is studied under determined hydraulic conditions. The flow field around the modified Savonius turbine is interpreted by the 3D streamlines and pressure contours. The obtained results indicate that increasing the turbine blade numbers up to 5 and more causes the turbine efficiency first to rise and then to fall, respectively.

\section{Introduction}

The use of excess potential energy in urban and rural water pipelines is a new source of clean energy. This surplus energy can be created by hydraulic head generated as a result of the high altitude difference between the origin and the destination of the pipeline or by the pumping station. Generally, in the sense of reducing the excess pressure in the pipelines, a pressure relief valve or the atmospheric reservoir is employed [1], while making use of this extra potential energy for electricity generation meanwhile solves leakage pipeline problems as well [2-4].

The conventional turbines in small dimensions can potentially be the first idea to utilize hydraulic energy. However, the limitation of pressure drop in water pipelines along with the design requirements of the piping network, choosing an appropriate type of turbine type, is a challenging issue.

Several researchers have examined small scaled propeller or axial turbines [5-8], but the initial design cost and manufacturing of these turbines are relatively high. Moreover, downsizing of these turbine types causes sharply decreasing of efficiency. In the interest of overcoming these issues, some researchers have presented general geometries to reduce the design costs $[9,10]$ and increase the efficiency by optimizing the turbine [11].

Using the pump in reverse mode (pump as turbine or PAT) that was first proposed by Thoma and Kittredge [12] is an uncomplicated technique with a low initial cost for power production. Though employing the PAT looks simple and also causes decreasing the initial project cost, due to the lack of reliable guidance in selecting proper pump and also fluctuating flow rate conditions in the piping network, this makes this approach unreliable for this purpose [2]. It should be mentioned that the flow rate changes strongly affects the efficiency of the PAT, so employing the mentioned turbine in the water supply system, which is usually variable in flow rate, may not be appropriate [13]

As a third alternative, the use of vertical axis free flow turbines in a pipe has recently been raised. Darrieus and Savonius rotor turbines are the most commonly used vertical axis free flow turbines and work on the basis of lift and drag forces, respectively. These spherical-shaped turbines 


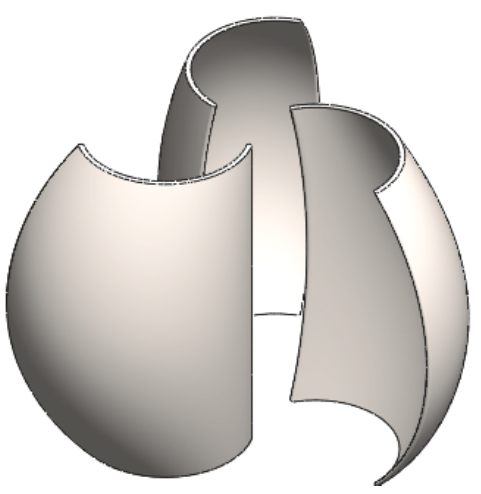

(a)

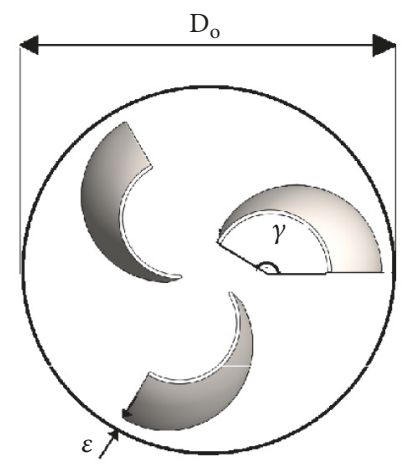

(b)

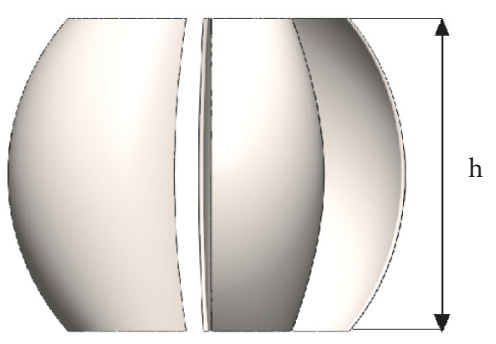

(c)

FIgURE 1: 3-bladed in-pipe Savonius turbine: (a) Isometric view; (b) top view; (c) front view.

have 5 blades and the minimum diameter of the pipe for installation is 24 inches [14]. The Savonius turbine has been employed in a confined section such as duct and improved its efficiency $[15,16]$. For once, Chen et al. [17] attempted to use a turbine similar to the Savonius turbine in a 4inch tube. They evaluated the drag-based turbine under defined hydraulic conditions. Various experiments are the most obvious points of their work, while the numerical results presented are not significant due to the limitation of the computational tools. The results of Chen et al. [17] prove that the utilization of lift-based turbines in small pipes do not have acceptable performance. Therefore, drag-based turbines are more suitable for using the excess energy of the small pipelines. More recently, Ma et al. [18] have studied and tested a cross-flow turbine for a 4-inch tube and lift-based turbine for a 10 -inch tube. They examined several methods to increase in-pipe cross flow. Given that the free flow turbines do not cause much pressure drop, using them in urban and rural water supply pipelines may guarantee a sufficiently high pressure in the standard range, in addition, to generate power from excess water potential energy. Whereas the use of the Savonius turbine inside the tube has not been utilized much in history, the effect of different geometric parameters of turbines has not been thoroughly investigated. Although some studies show that the efficiency of free flow Savonius turbine reduces by increasing the blade number above 2 [19-21], Chen et al. [17] proposed a 12-bladed turbine as the best case. It indicates the important role of the blade numbers effects on such turbine types. Ma et al. [18] showed that increasing the blade number of in-pipe from 6 to 12 increases turbine efficiency by up to twice. Fazlizan [22] has also proven (by testing a drag-based turbine in a wind tunnel) that the turbine efficiency can be improved by increasing the number of Savonius turbine blades merely in duct cross section. Irabu and Roy [23] studied the effect of surrounding the turbine with a guide box and found increases about 1.5 times with three blades and 1.23 times with two blades greater than that without guide-box tunnel, respectively. In another study, Ahmed et al. [15] examined a three-bladed Savonius turbine in a fully confined section, which shows an increase of $50 \%$ in efficiency than 2-bladed free flow turbine. Therefore, increasing the number of blades for a free flow Savonius turbine leads to a reduction in efficiency and, for internal flow Savonius turbine, increases efficiency.

The effect of the number of the blades on the performance as well as the flow field around a small-scale in-pipe Savonius turbine has not been investigated yet. Firstly, an in-pipe dragbased turbine design procedure is described in the present paper. Secondly, in connection to the performed experimental studies, the effect of the blade numbers of a modified Savonius turbine on its performance under certain conditions is investigated numerically. Also, the effect of blade number on the flow field is explained by pressure contours and 3D streamlines graphically.

\section{Turbine Design}

There is no comprehensive research on the effect of various small in-pipe turbine geometric parameters, such as blade profile, number of blades, height and thickness of blades, etc. In this research, except the number of blades, the other turbine geometry parameters are considered invariable and these mentioned parameters are chosen based on the related existing experiences. As the first parameter, the profile of the blade is taken into consideration. The blade profile of the modified turbine which is inspired by the Savonius turbine is part of a semicircle circumference. Chen et al. [17] did not present turbine profile in their design but showed that empty turbine center (or hollow shaft) could play a significant role in increasing turbine efficiency. For this reason, in the present design, instead of using a full semicircle $\left(180^{\circ}\right)$, a $150^{\circ}$ arc is used. Figure 1 shows an example of a 3-bladed turbine.

The modified turbine is designed in such a way to have the same profile for all sections. In other words, each section of a turbine with other sections is similar, and only its size varies with respect to the circle of the pipe section chord. Another important parameter is the height of the turbine, which is considered to be $70 \%$ pipe diameter due to the convenience of installation into the pipe. According to the dimensions provided by Chen et al. [17], the turbine clearance is set to $4 \mathrm{~mm}$. 
TABLE 1: Essential geometry of the turbine and deflector parameters value.

\begin{tabular}{lcc}
\hline Description & sign & value \\
\hline Pipe diameter & $D_{o}$ & $100(\mathrm{~mm})$ \\
Circle arc degree & $\gamma$ & $150^{\circ}$ \\
Height of the turbine & $h$ & $70(\mathrm{~mm})$ \\
Clearance & $\varepsilon$ & $4(\mathrm{~mm})$ \\
Deflector angle & $\alpha$ & $20^{\circ}$ \\
X-intercept & $X$ & $30(\mathrm{~mm})$ \\
\hline
\end{tabular}

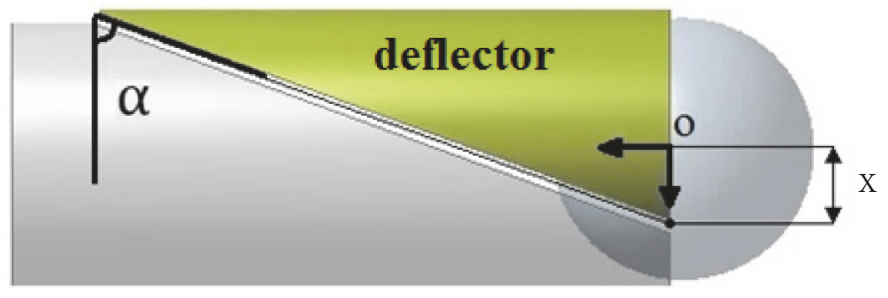

(a)

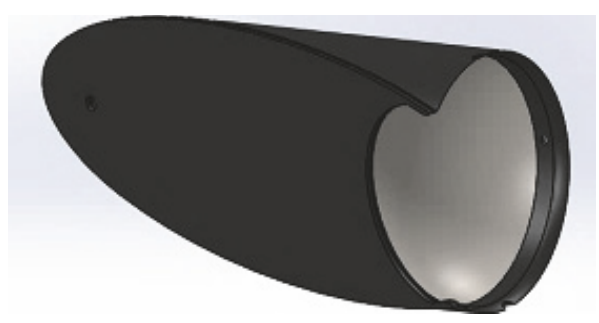

(b)

FIGURE 2: Schematic of constant slope deflector: (a) upper view and (b) isometric view.

Earlier studies on the free flow Savonius turbine [25-32], as well as Chen et al. [17] experiments, show that the use of a deflector has a significant role in increasing the efficiency of the drag-based turbines. A constant slope deflector that is similar to the third-type deflector of Chen et al.[17] is selected. The deflector slope is $20^{\circ}$ and is designed in such a way that the entire stream meets the advancing blades and prevents collisions with returning blades directly. The cross-sectional area of the pipe covered by the diffuser is about $80 \%$.

The schematic geometry of the deflector is shown in Figure 2, which is obtained by cutting off a cylinder by a hemisphere and a constant slope plate with determined Xintercept. Table 1 shows the values of the geometry of the turbine and the deflector.

\section{Experimental Setup}

In order to investigate the turbine performance experimentally and validate numerical simulation, an experimental laboratory rig is designed and constructed. The laboratory rig is open and operates under a constant pressure difference which is created by a reservoir with a height of 4 meters. The test rig includes an atmospheric reservoir, a shut-off valve, a mercury manometer, a test section, a globe valve, and a flexible hose. Figure 3 shows an overview of the laboratory rig. Measuring instruments include mercury manometer, optical tachometer, and calibrated tank to measure the flow rate. The full-scale accuracy of pressure measurement and tachometer is $\pm 1 \%$ and $\pm 0.5 \%$, respectively. Also, the standard error of the flow rate and uncertainty is estimated to be $\pm 0.098 \%$ and $\pm 0.15 \%$, according to the conventional method [33].

Since the main purpose of the experimental test is the validation of numerical simulation results, one turbine geometry consideration may be adequate. Based on this argument, a two-bladed turbine, as well as the described deflector, is made by a $3 \mathrm{D}$ printer and then installed in a $100-\mathrm{mm}$ transparent pipe. Figure 4 shows the fabricated test section.

The tests are carried out for 7 operating conditions and the values of the flow rate, rotational speed, and pressure difference (as turbine head) are measured. The torque applied to the turbine shaft is only due to the friction of the mechanical seals and bearings. Thus, it is expected to remain constant during the tests.

The method of doing the test describes as follows. First, the globe valve rests in a constant state. Then, the atmospheric reservoir is fed by a pump to the overflow state. In the next step, the shut-off valve which is at the beginning of the 4-inch line opens completely. The flow passes through the turbine and, after ensuring the stability of the test conditions, the values of the pressure difference, rotational speed, and discharge are measured and recorded. Then, without changing the state of the globe valve, the experiment repeated several times for this condition, and, eventually, its average value is reported. By changing the position of the globe valve, a new operating condition for the turbine is created. Table 2 summarizes the experimental results.

\section{Numerical Simulation}

The simultaneous progress of computing tools and CFD techniques expanded the use of numerical simulations to examine various engineering issues. In the present study, numerical simulation is employed to investigate the number of turbine blades effect on turbine behavior. To simulate the flow field around the turbine a commercial software (FLUENT 18) is utilized. In order to validate the simulation, it is necessary to simulate the turbine condition in the experimental conditions essentially. After validating the simulation, the number of blades is changed and their numerical estimates are made. As the number of turbine blades changes from 2 to 10 , a 


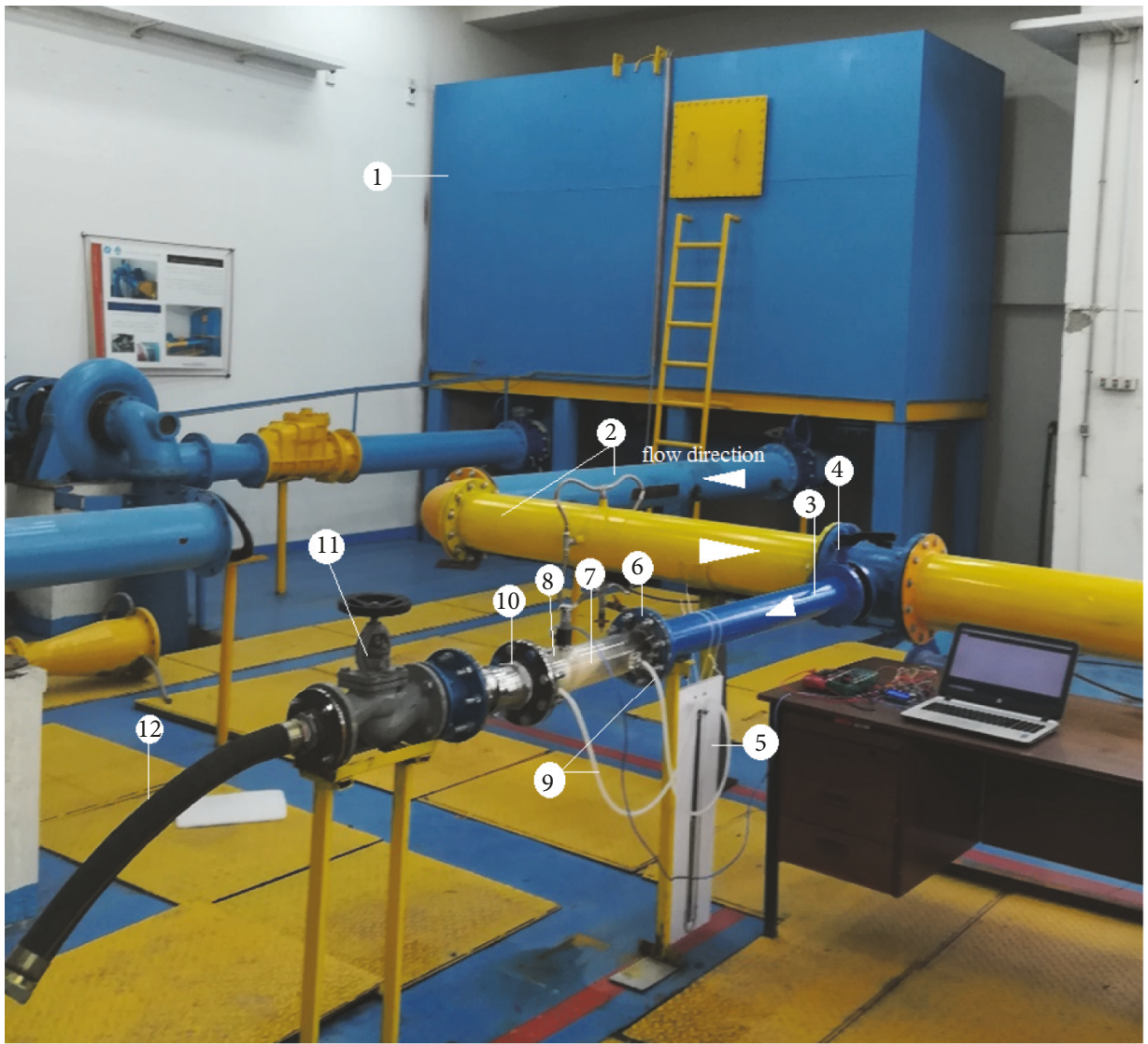
1. atmoapheric tank
2. 10-inch pipe
3. 4 -inch pipe
4. cut-off valve
5. manometer
6. inlet of test section

7. block

8. turbine

9. manometer hose

10. outlet of test section

11. globe valve

12. flexible tube

FIgURE 3: Test rig and its components [24].

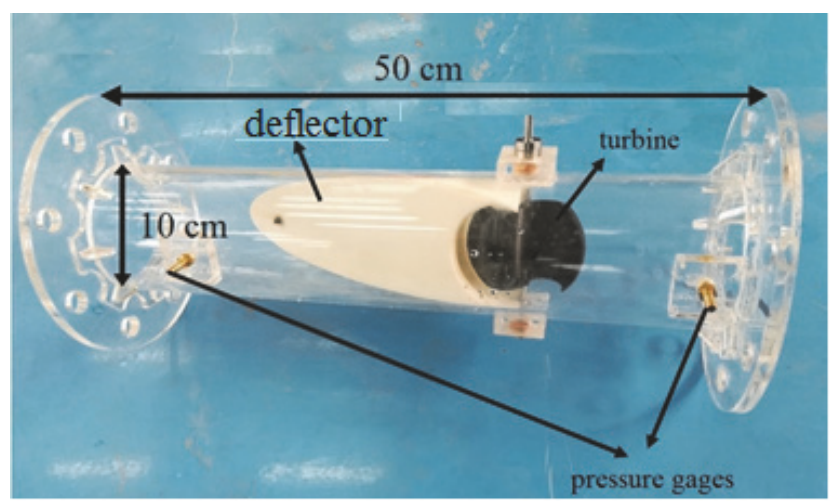

Figure 4: Two-bladed turbine test section with deflector.

transient mode of the problem is considered. Although for multi-bladed turbines, it is possible to assume a steady state condition, transient mode is considered here. The sliding mesh technique has been used here. In the sliding mesh method, the domain of the solution is divided into two rotating and stationary zones. Rotating volume includes turbine blades and constant volume including inlet and outlet pipes and the deflector. The boundary conditions applied to the turbine, including the total and static pressure at the turbine inlet and outlet (approximate for head turbine values is $20 \mathrm{kPa}$ ), respectively and constant rotational speed (50 $\mathrm{rad} / \mathrm{s})$.

The flow field domain in numerical simulation consists of an inlet pipe, deflector zone, turbine and an outlet pipe which are shown in Figure 5.

Modeling the fluid flow passing through the turbine is performed by using RANS equations. Among the turbulence models, the most suitable model to simulate turbomachines is the $k-\omega S S T$ model [34]. The $k-\omega S S T$ turbulence model is recommended by Menters [35-37] and has positive features of the $k-\varepsilon$ and $k-\omega$ models simultaneously. With this explanation, the $k-\omega S S T$ model is chosen for simulation. Also, to evaluate performance of turbine a non-dimensioned parameter, efficiency, is applied and defined as follow:

$$
\eta=\frac{T \Omega}{\Delta P Q}
$$


TABLE 2: Test results in turbine different operating conditions.

\begin{tabular}{lccc}
\hline Operating Conditions & $\dot{Q}\left(\mathrm{~m}^{3} / \mathrm{s}\right) \times 10^{3}$ & $\Delta P(\mathrm{mmHg})$ & $\Omega(\mathrm{rad} / \mathrm{s})$ \\
\hline 1 & 2.71 & 10 & 18.2 \\
2 & 3.86 & 30 & 30.1 \\
3 & 4.72 & 35 & 40.6 \\
4 & 4.95 & 43 & 44.4 \\
5 & 5.83 & 69 & 53.2 \\
6 & 7.02 & 80 & 68.7 \\
7 & 7.31 & 75.5 \\
\hline
\end{tabular}

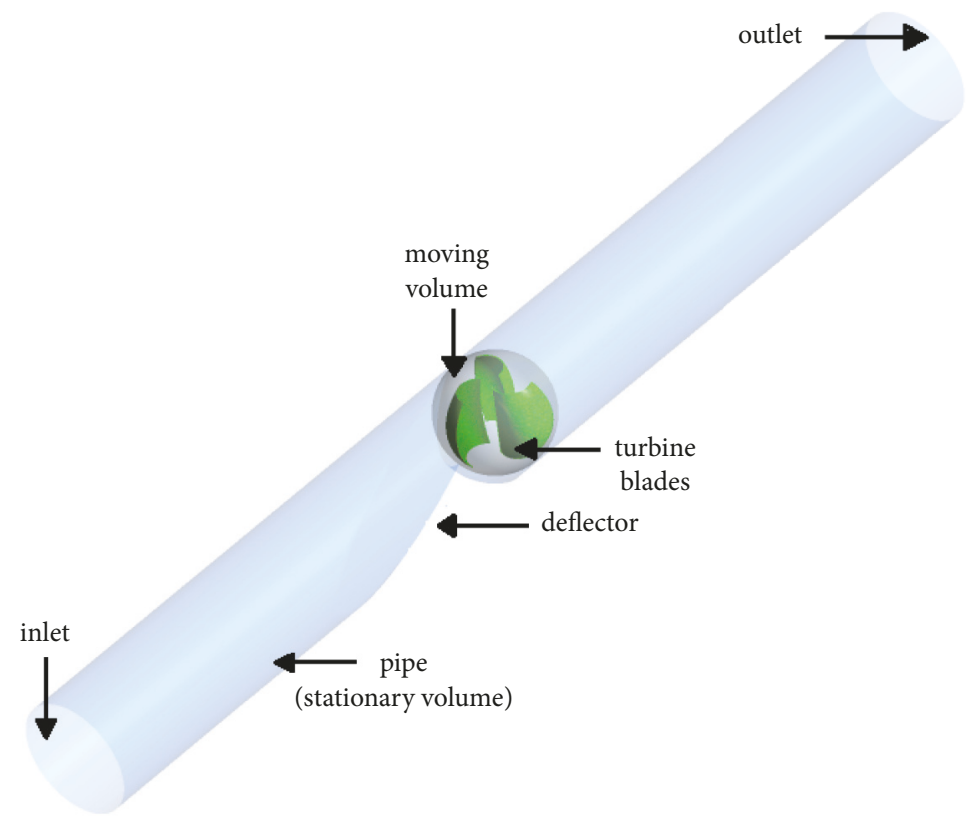

FIGURE 5: Numerical flow field domain components.

The convergence criteria for RMS residuals of continuity, momentum, and turbulence quantities were set to $10^{-5}$ as well.

\section{Mesh and Time Step Independency}

Increasing the number of elements, as well as reducing the time step, will increase the simulation accuracy. But, it also increases the time of simulation. The mesh used for fluid domain is such that average $\mathrm{y}^{+}$(which defines distance of first mesh node from the wall) is 2.1 with $\mathrm{y}^{+}$ranging between $\left(0.6<\mathrm{y}^{+}<9.5\right)$ for the highest flow speed case, i.e., 2 -bladed turbine. Reynolds averaged Navier-Stokes (RANS) equations were solved using $k$ - $\omega S S T$ turbulence model for which $\mathrm{y}^{+}<10$ is acceptable for predicting boundary layer separation effects [38]. In order to consider the wall effects on the flow physics properly, it is necessary to apply the Prism layer to all the walls of the discrete domain. Hence, by using the inflation mesh option in ANSYS Mesh software, the grid network of the solution domain is made finer around the blades and pipe wall. At each level of mesh refinement, the cell size is reduced $30 \%$ approximately, and the thickness of the prism layer is estimated using the online calculator [38] based on velocity, water physical properties, and geometry. But, the thickness of the prism layer is constant, and only the number of layers becomes one more in each refinement level. At last $y^{+}$is checked for all solutions to be within the desired range. By the try and error method, 8 layers with a growth ratio of 1.05 seemed adequate. Initially, for the 2-bladed turbine, the mesh independency was conducted in 4 levels and for other turbines, grid independency was checked. The method of checking for other turbines has two steps. Firstly, the cells size, the number of edge divisions and prism layer that were obtained adequate in the 2-bladed turbine were also applied to the other turbines and efficiency was evaluated. Secondly, with increasing number of cells, mesh independency was examined by comparing efficiency. Table 3 shows the results of a finer grid network for all turbines under a differential pressure of $20 \mathrm{kPa}$ and a rotational speed of $50 \mathrm{rad} / \mathrm{s}$.

According to Table 3, the number of 5.1 to 6.2 million units seems to be sufficient for 2-bladed to 10-bladed turbines, respectively.

Cell size, division number, and prism layer for all turbine are identical but the number of cells is different, because 
TABLE 3: Grid number vs. efficiency for all turbines.

\begin{tabular}{|c|c|c|c|c|c|}
\hline & & 1 & 2 & 3 & 4 \\
\hline Grid number & \multirow{4}{*}{ 2-bladed turbine } & $1.5 \times 10^{6}$ & $2.8 \times 10^{6}$ & $5.1 \times 10^{6}$ & $7.6 \times 10^{6}$ \\
\hline Efficiency & & 19.22 & 16.01 & 14.15 & 14.12 \\
\hline Torque change & & - & $7.51 \%$ & $2.39 \%$ & $1.29 \%$ \\
\hline Flow rate change & & - & $4.9 \%$ & $3.21 \%$ & $1.86 \%$ \\
\hline Grid number & \multirow{4}{*}{ 3-bladed turbine } & & & $5.3 \times 10^{6}$ & $7.9 \times 10^{6}$ \\
\hline Efficiency & & & & 22.10 & 22.09 \\
\hline Torque change & & & & - & $1.72 \%$ \\
\hline Flow rate change & & & & - & $1.96 \%$ \\
\hline Grid number & \multirow{4}{*}{ 5-bladed turbine } & & & $5.6 \times 10^{6}$ & $8.2 \times 10^{6}$ \\
\hline Efficiency & & & & 28.15 & 28.14 \\
\hline Torque change & & & & - & $1.29 \%$ \\
\hline Flow rate change & & & & - & $1.67 \%$ \\
\hline Grid number & \multirow{4}{*}{ 8-bladed turbine } & & & $5.8 \times 10^{6}$ & $8.8 \times 10^{6}$ \\
\hline Efficiency & & & & 26.41 & 26.41 \\
\hline Torque change & & & & - & $1.11 \%$ \\
\hline Flow rate change & & & & - & $1.37 \%$ \\
\hline Grid number & \multirow{4}{*}{ 10-bladed turbine } & & & $6.2 \times 10^{6}$ & $9.5 \times 10^{6}$ \\
\hline Efficiency & & & & 24.66 & 24.66 \\
\hline Torque change & & & & - & $1.02 \%$ \\
\hline Flow rate change & & & & - & $1.16 \%$ \\
\hline
\end{tabular}

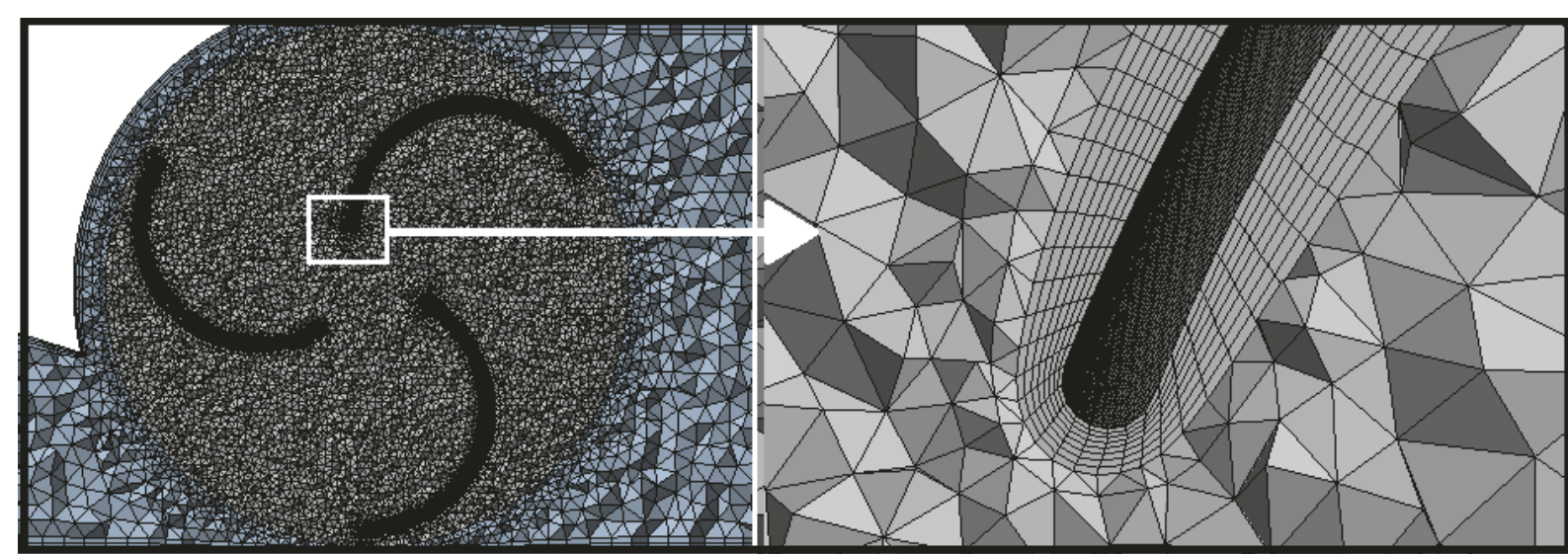

(a)

FIGURE 6: Generated Grid: (a) around the 3-bladed turbine and (b) prism layer around the blade.

prism layer grid number increased by increasing blade number, i.e., walls.

Another investigation that seems to be necessary is the interface location. The interface, which is, in fact, the boundary of the moving volume and stationary volume, is a $96-\mathrm{mm}$ diameter sphere, where the clearance is $4 \mathrm{~mm}$ and turbine diameter is $92 \mathrm{~mm}$. Also, with a change in the diameter of the interface sphere to $94 \mathrm{~mm}$ and $98 \mathrm{~mm}$, there was insignificant effect on the results. It seems that the small dimensions of the turbine and the clearance have a negligible impact on the results of the interface diameter. Figure 6 shows the quality of the mesh around the blades of three-bladed turbine elements.

Time step may impact the accuracy of the simulation. Thus time step independency is considered separately. Time step was selected such that turbine rotated $1^{\circ}$ during each time step which leads to average CFL (Courant Friedrichs Lewy condition) number of less than 5. CFL number defines a necessary condition for numerical stability of a hyperbolic partial equation [39].

Present CFD analysis was conducted with an implicit solver within Fluent for which CFL $<5$ was acceptable [40]. Moreover, to check the convergence with respect to time step size, a time step independency was done by varying time step size such that the turbine shaft rotated $5^{\circ}, 3^{\circ}, 2^{\circ}, 1^{\circ}$, and $0.5^{\circ}$ per time step. Table 4 shows the result for 2 -bladed and 10-bladed turbines separately. Thus a time step that corresponds to $1^{\circ}$ rotation was chosen for present numerical study. 
TABLE 4: Time step reduction effect on simulation.

\begin{tabular}{|c|c|c|c|c|c|}
\hline Time step (s) & $1.7 \times 10^{-3}$ & $1.0 \times 10^{-3}$ & $7.0 \times 10^{-4}$ & $3.5 \times 10^{-4}$ & $1.7 \times 10^{-4}$ \\
\hline Degree(s) in a time step & $5^{\circ}$ & $3^{\circ}$ & $2^{\circ}$ & $1^{\circ}$ & $0.5^{\circ}$ \\
\hline 2-bladed turbine efficiency & 17.11 & 15.34 & 14.37 & 14.15 & 14.13 \\
\hline 10-bladed turbine efficiency & 28.52 & 25.86 & 24.93 & 24.66 & 24.66 \\
\hline
\end{tabular}

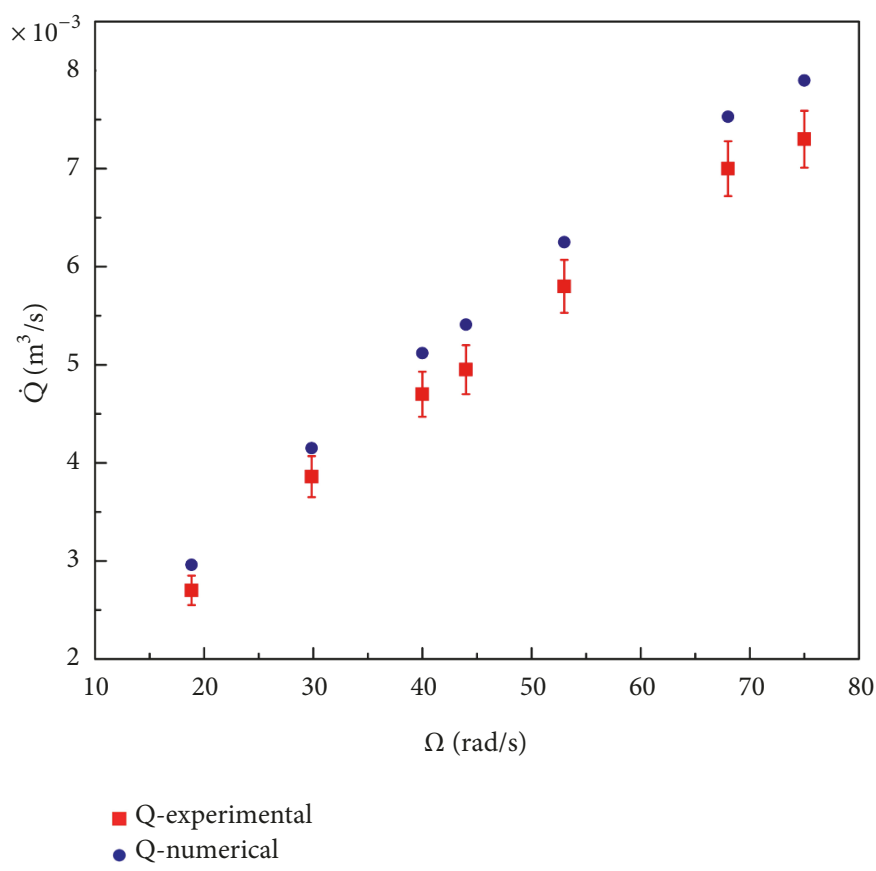

Figure 7: Comparison between laboratory results and numerical simulation [24]. The error bars represent the standard deviation of measurements for 5 repetitions of every operating condition.

Table 4 also shows that the turbine with 10 blades in the larger time step size reaches a reasonable accuracy, because, as the number of blades increases, the transient nature of the problem decreases.

\section{Numerical Validation}

Before simulations are extended to turbines with more than two blades, a comparison between experimental results and numerical simulations of a 2-bladed turbine is proposed. Figure 7 depicts the flow through the turbine in laboratory conditions and the simulation results.

Although the average difference between numerical and experimental results is about $10 \%$, the numerical simulation trend is completely in line with experimental results.

The almost linear relationship between rotational speed and flow rate indicates that this turbine can also be considered as a flowmeter. Due to complexities for geometric definitions such as surface blade roughness and turbine shaft that acts as a resistance in passing fluid flow it was not taken into account in numerical evaluation. This is probably the reason that numerical evaluation over predicts flow rate with respect to the experimental results; however, the difference within the numerical and the experimental results has decreased considerably with respect to the previous related studies $[17$,
19]. To ensure correct approach, despite highly increasing the CPU time, the fluid flow inside the turbine with more accurate geometry (considering turbine shaft and consequently complicated meshes) was simulated. This was performed only for the worst case in terms of error and obtained result showed significantly decreasing in flow rate prediction (about $4.5 \%$ error). However, due to simplification, the simulation results are presented regardless of the geometry of the shaft.

\section{Results and Discussion}

The results are obtained at a constant pressure difference of $20 \mathrm{kPa}$ and a rotational speed of $50 \mathrm{rad} / \mathrm{s}$ for a turbine with a number of blades from 2 to 10. Figure 8 shows the efficiency, torque, and discharge relative to the increase in the number of blades.

Obviously, increasing the number of blades causes a decrease in the flow through the turbine due to increased turbine hydraulic resistance.

In other words, adding any blade means increasing the hydraulic resistance. Because the flow with more obstacles (blades) collides, therefore, in boundary conditions, which is the difference in pressure between the two sides of the turbine (constant turbine head), increasing hydraulic resistance leads to a decrease in the flow through the turbine. 


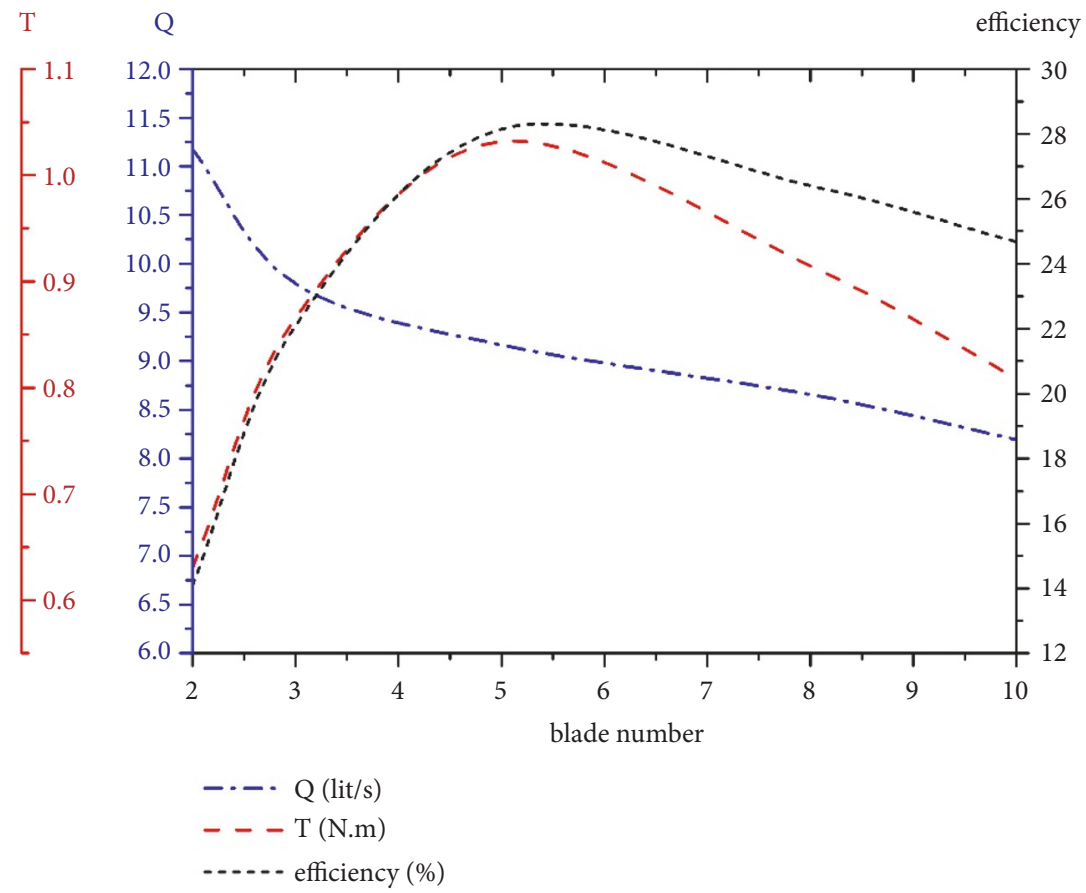

FIGURE 8: Flow rate, efficiency, and torque change vs. blade number.

Another point is the rate of the flow rate changing, which is declined sharply from 2-bladed to 3-bladed turbine, but this rate becomes lower for more blades. The turbine leakage seems to be drastically reduced, with the number of blades increasing from two to three, but with a further increase in the number of blades from three, there is no dramatic reduction in leakage. Due to the large distance between the two blades in the 2-bladed turbine, in some angular positions of the turbine during its rotation, the flow does not collide with any blades and passes through the turbine. By increasing the number of blades to three, the positions where the flow does not collide with any blades are greatly reduced and the leakage from the turbine decreases accordingly. But more increasing in blades number (from 3 blades) does not have much effect on reducing leakage from the turbine during its rotation, which is why the rate of reduction in the discharge is reduced.

Obtained results also indicate an optimum value for the efficiency and the torque. It seems that this behavior comes from the fluid flow and turbine blades interaction. In the turbine with a low blade number, a major portion of the fluid flow passes inside the turbine without having effective contacts with the blades. This causes lower useful torque and consequently efficiency reduction. Over there, in the turbine with more than a specified blade number which is evidently dependent on the blade size and its rotational speed; the passing flow does not have completely positive influences on the turbine blades (as a result of blades overlapping). Thereby, torque decreasing as well as flow rate reduction due to the increasing blade number causes a reduction in turbine efficiency. In other words, the lower blades cause more leakage and more blades, due to overlapping, prevent the proper flow impact on the blades. Given that the rate of the torque and the efficiency changing for turbines with blades more than 5 is less than the rate of the changes for turbines with blades less than 5 , it can be concluded that the negative effect of leakage is greater than the negative effect of overlapping on the efficiency.

Since the study on the fluid flow passing through the turbine might provide a deeper understanding of the above descriptions, the pressure contours and the streamlines are investigated. In this regard, one turbine position is chosen from the $360^{\circ}$ trip. Selected state is the case where one blade is completely in front of the flow.

Figure 9 depicts the position of the turbine blades for comparison. Figures 10-12 illustrate the pressure contour and streamlines for three turbines with different blade numbers. Pressure contours for each turbine are displayed from two directions to determine the pressure distribution on both sides of the blades.

Considering the direction of turbine rotation (clockwise), increasing pressure in concave surfaces means increasing the positive torque and increasing the pressure on the convex surfaces means reducing the positive torque generation. Figure 10 demonstrates the simulated flow field pressure contour and streamlines for the turbine of 3-bladed. As it is viewed, meanwhile the main portion of the passing flow hits with the blade No. 1 and, consequently, the major part of the torque production is generated by this blade, and the other blades have high-pressure convex surfaces (Figure 10(a)) that reduce torque. Streamlines also indicate that the flow after passing through the blade No. 1 does not have a complete impact with the other blades

But in the turbine of the 5 blades, except for the concave surface of the blade No. 1, the concave surfaces of blades Nos. 


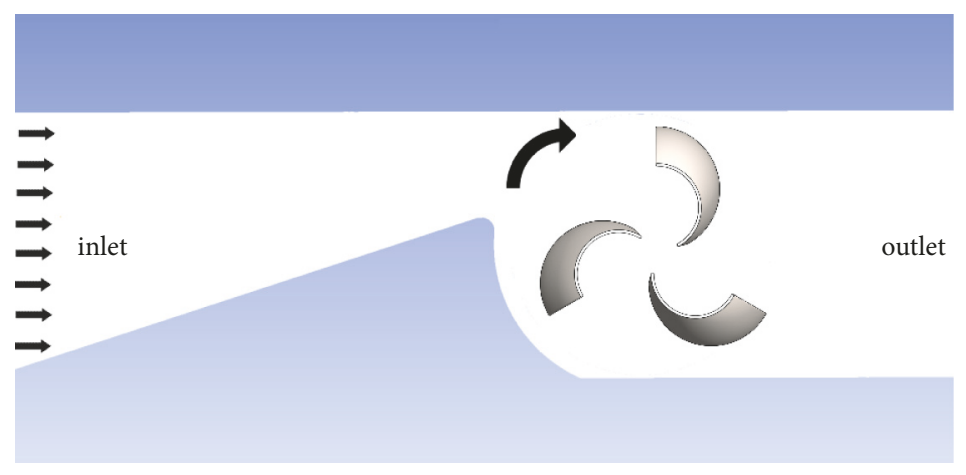

FIgURE 9: The position of the turbine blades for comparison.

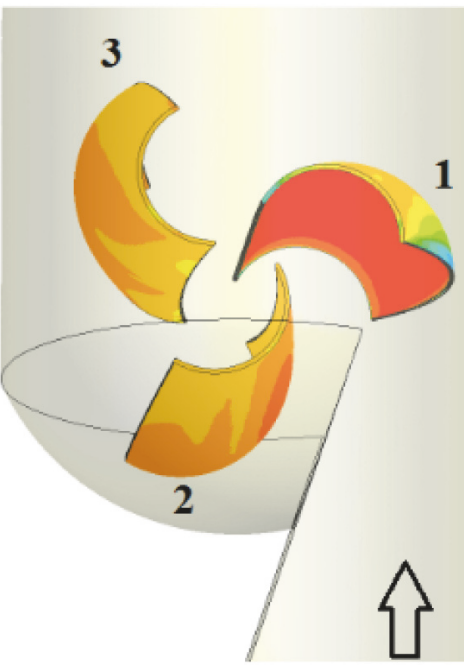

i
Pressure

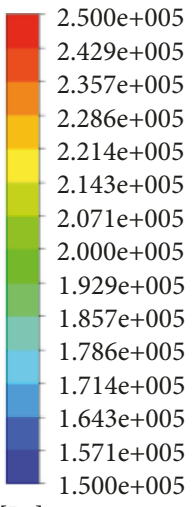

$[\mathrm{Pa}]$

$1.571 \mathrm{e}+005$

CCW

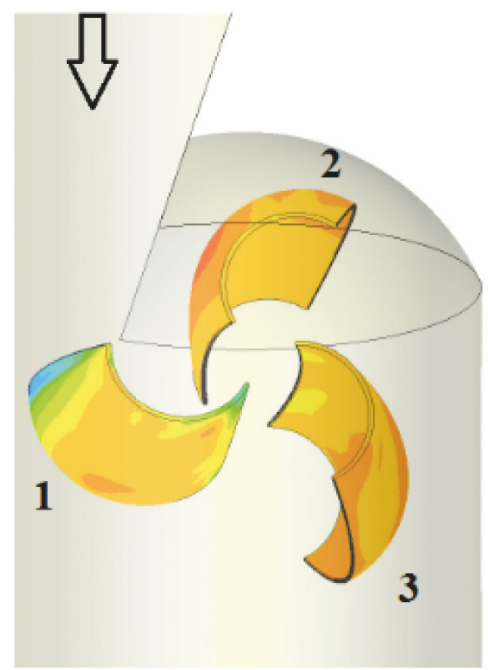

ii

(a)

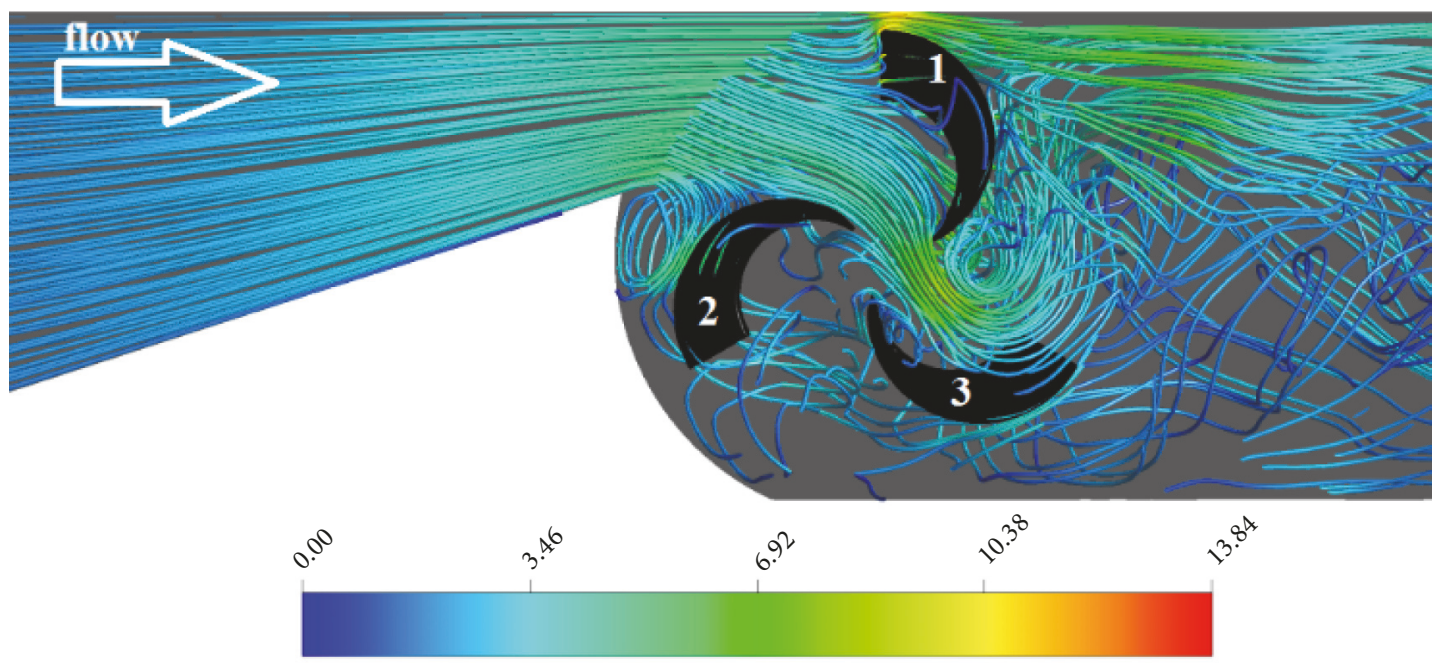

Velocity

(b)

FIGURE 10: The simulated fluid flow around the 3-bladed turbine: (a) pressure contours (i) in the direction of flow view and (ii) in the opposite direction of flow view and (b) top view of streamlines. 

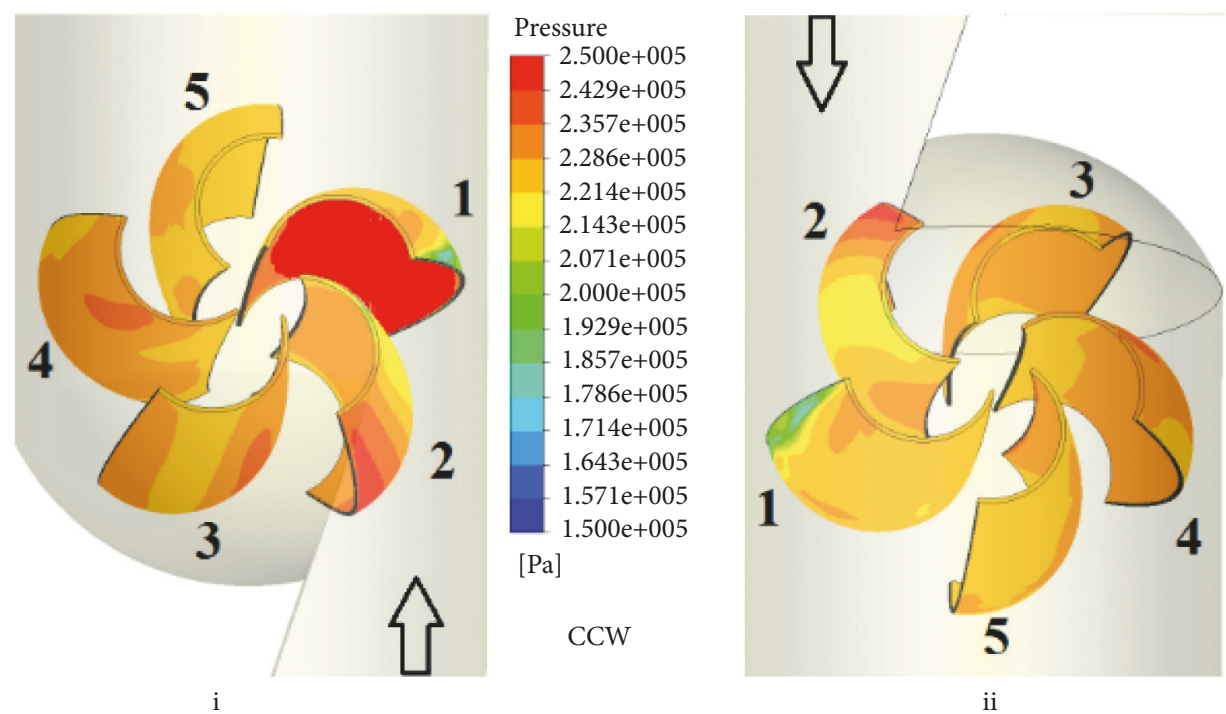

(a)

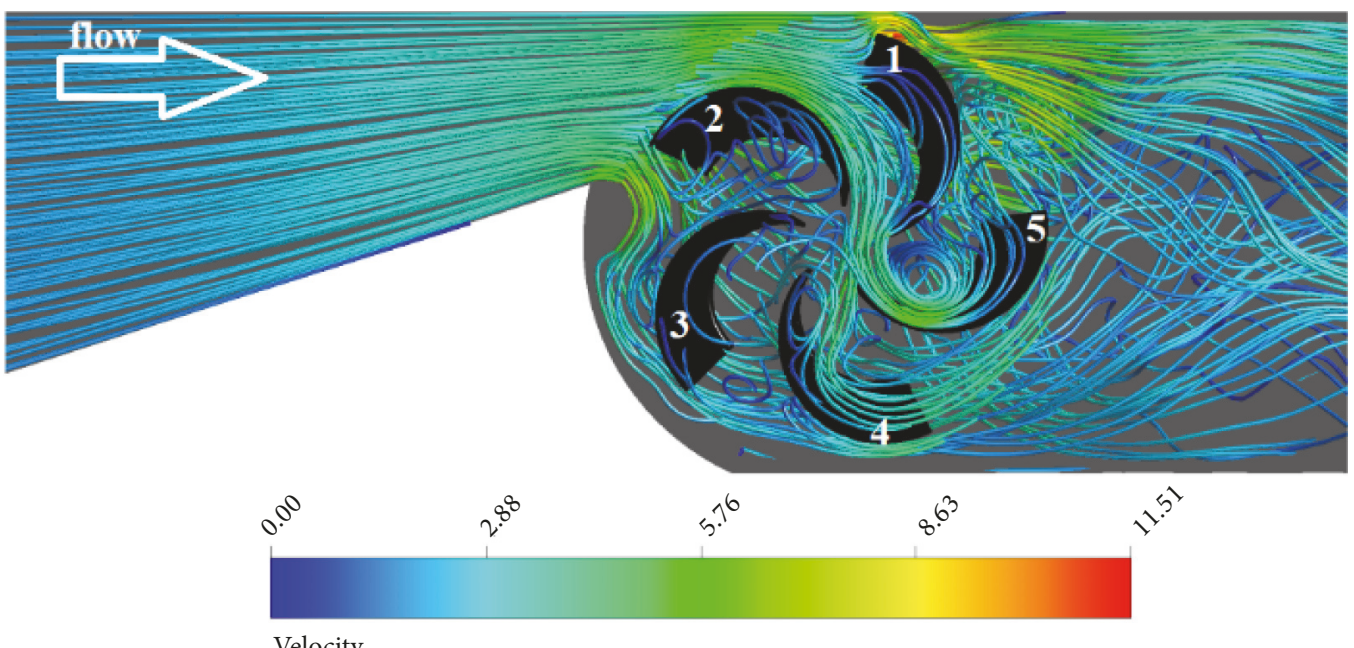

(b)

Figure 11: The simulated fluid flow around the 5-bladed turbine. (a) pressure contours (i) in the direction of flow view and (ii) in the opposite direction of flow view and (b) top view of streamlines.

3 and 4 also have a higher pressure than their convex surfaces (see pressure contour of Figure 11). In the other state, the 3bladed turbine may not use all capacity of flow potential.

By comparing the streamlines of 3-bladed and the 5bladed turbines (Figures 10(b) and 11(b)), it is clear that the flow in the 3-bladed turbine, after passing through the blade No.1, leaves the turbine without impact with other blades. While in the 5-bladed turbine, the flow after meeting the blades Nos. 1 and 2 hits the concave surfaces of blades Nos. 3 and 4 (see Figure 11(b)).

For this reason, the generated torque of the 5-bladed is increased compared to the 3-bladed turbine; however, the flow rate is decreased. In other words, the proper fitting of the blades in the 5-bladed turbine causes the flow to meet twice with each blade in a $360^{\circ}$. The streamlines in Figure 11(b) clearly show that the flow after the collision with the 1st and 2nd blade hits the concave surface of blades Nos. 3 and 4 and then leaves the turbine.

According to Figure 12, the concave surfaces of the blades No.1, 2, and 6 are under high pressure, while the convex and concave surfaces of the other blades are under the same pressure.

It seems that the cause of the reduction in the efficiency of the 8-bladed turbine is related to several factors. The first is to reduce the flow rate, which reduces the pressure on the blades generally. The second is to divide the flow into blades No. 1 and No. 2, which causes the surfaces to not be under maximum pressure (compare pressure contours of Figures 10 and 11 with pressure contours of Figure 12). Thirdly, an inappropriate collision of the flow with blade No. 3 that produces undesired torque and consequently reduces positive torque. In Figures 10-12, the positive effect of the hollow shaft 

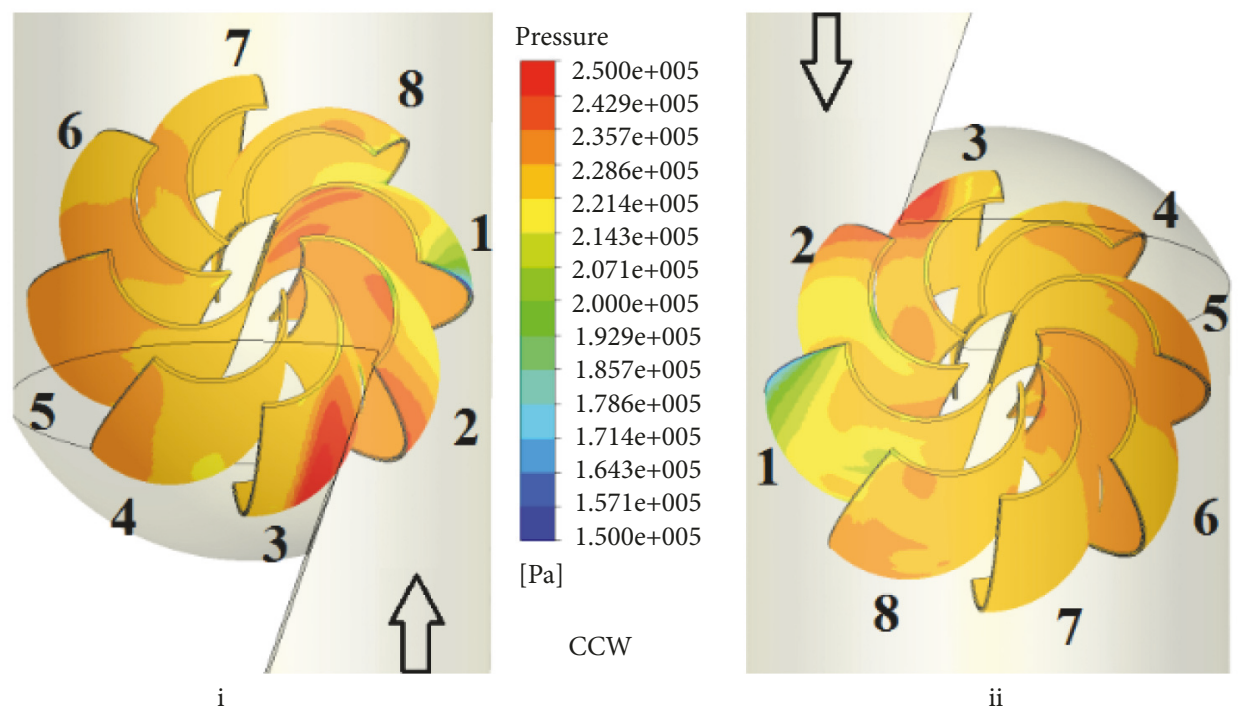

(a)

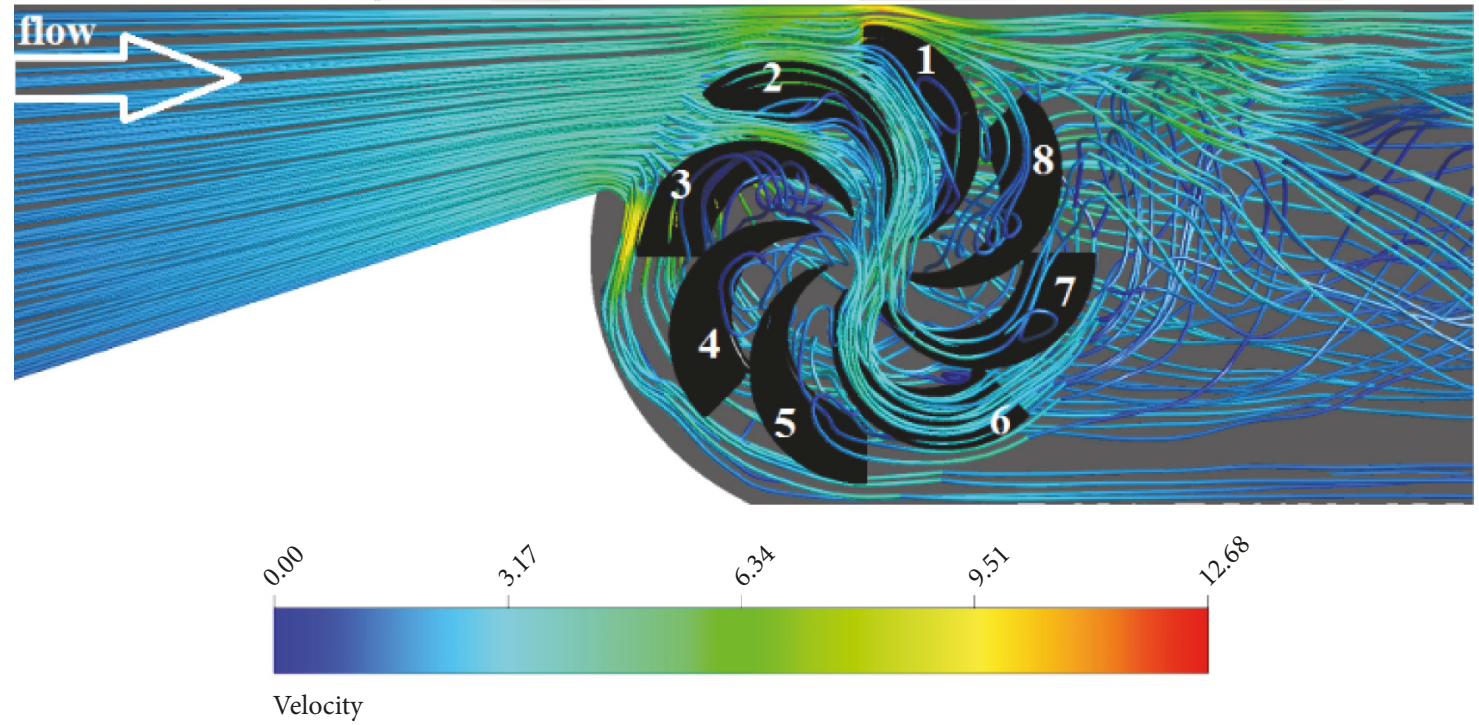

(b)

FIGURE 12: The simulated flow field around the 8-bladed turbine. (a) Pressure contours (i) in the direction of flow view and (ii) in the opposite direction of flow view and (b) top view of streamlines.

is well seen, where the flow is allowed to meet a larger number of blades and the turbine extracts more power.

In order to detect more precisely, the normalized flow rate and net torque at $360^{\circ}$ of turbine rotation are plotted for turbines 3, 5, and 8 of the blade in Figures 13(a) and 13(b), respectively. In Figure 13(a) flow rate at each time step (or turbine position) is normalized with a mean flow rate at a rotation. As shown in the Figure 13(a), the increase in the number of blades reduces the oscillation of the discharge. In other words, the flow rate becomes more uniform. This is probably due to the turbine geometry and reduces the space between the blades. This uniformity in discharge results in more uniform torque generation (see Figure 13(b)).
As it is clear in Figure 13(b), the 3-bladed turbine torque and flow rate fluctuate more than turbines with more blades. Also, the number of fluctuation events in one revolution increases because the number of blades is increased. The maximum torque in a cycle belongs to the 3-bladed turbine, but minimum torque is generated by this turbine too. Thus, the average torque of the 5-bladed turbine is more than others.

\section{Conclusion}

In the present study, an in-pipe drag-based turbine which is inspired by a Savonius rotor turbine for a diameter of 4 inches 


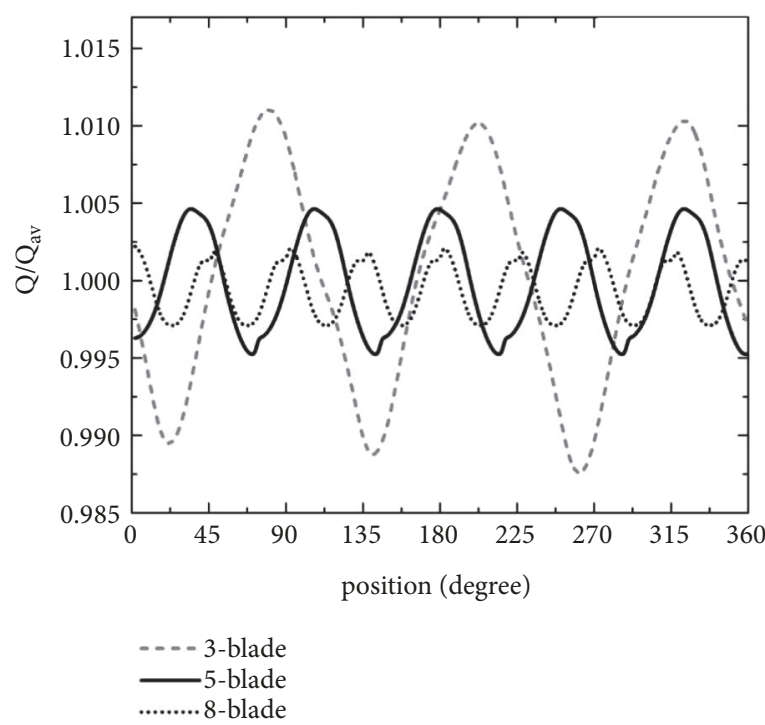

(a) .

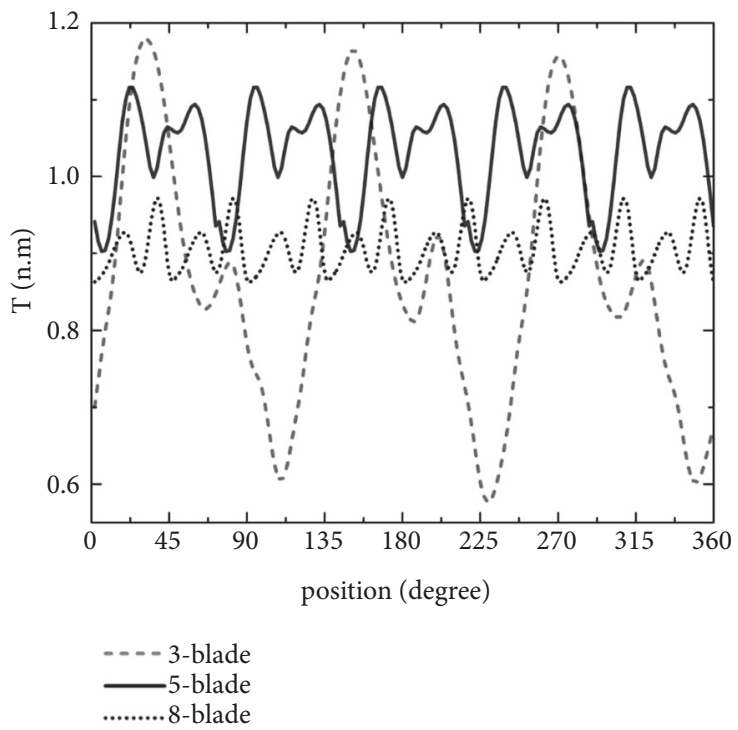

(b)

FIGURE 13: (a) Normalized flow rate and (b) generated torque for one revolution.

is designed. A prototype of the turbine is examined in the test rig, and, after assuring matching the results of numerical simulation and laboratory, the effect of increasing the number of turbine blades is investigated numerically. The results show

(i) Increasing the number of in-pipe turbine blades up to 5 blades efficiency is improved.

Increasing the number of blades, more than 5 , reduces the efficiency due to increased turbine hydraulic resistance and inadequate impact of the fluid with blades.

(ii) Turbines with a number of blades less than 5 are less efficient than the optimum mode because they cannot use all of the potential flow capacity. (iii) The use of the hollow shaft turbine could allow the flow to pass properly through turbine blades and bring increased efficiency.

(iv) Uniformity of the flow and torque is the effect of increasing the number of turbine blades.

\section{Data Availability}

No data were used to support this study. In this study we used our experiments that are included within the article.

\section{Disclosure}

Amir F. Najafi is a Visiting Professor at the Institute of Fluid Mechanics, KIT, 76131 Karlsruhe, Germany. 


\section{Conflicts of Interest}

The authors declare that there are no conflicts of interest regarding the publication of this paper.

\section{References}

[1] N. Fontana, M. Giugni, and D. Portolano, "Losses reduction and energy production in water-distribution networks," Journal of Water Resources Planning and Management, vol. 138, no. 3, pp. 237-244, 2012.

[2] A. Carravetta, G. Del Giudice, O. Fecarotta, and H. M. Ramos, "Energy production in water distribution networks: A PAT design strategy," Water Resources Management, vol. 26, no. 13, pp. 3947-3959, 2012.

[3] A. McNabola, P. Coughlan, L. Corcoran et al., "Energy recovery in the water industry using micro-hydropower: an opportunity to improve sustainability," Water Policy, vol. 16, no. 1, pp. 168183, 2014.

[4] L. Corcoran, A. McNabola, and P. Coughlan, "Optimization of water distribution networks for combined hydropower energy recovery and leakage reduction," Journal of Water Resources Planning and Management, vol. 142, no. 2, 2016.

[5] K. Alexander, E. Giddens, and A. Fuller, "Axial-flow turbines for low head microhydro systems," Journal of Renewable Energy, vol. 34, no. 1, pp. 35-47, 2009.

[6] K. Alexander and E. Giddens, "Optimum penstocks for low head microhydro schemes," Journal of Renewable Energy, vol. 33, no. 3, pp. 507-519, 2008.

[7] A. Shkolnik, D. Littera, M. Nickerson, N. Shkolnik, and K. Cho, "Development of a small rotary SI/CI combustion engine," SAE Technical Papers, 2014.

[8] K. Alexander, E. Giddens, and A. Fuller, "Radial- and mixedflow turbines for low head microhydro systems," Journal of Renewable Energy, vol. 34, no. 7, pp. 1885-1894, 2009.

[9] D. Howey, "Axial flux permanent magnet generators for picohydropower," in Proceedings of the Proc. Eng. Without Borders UK Res. Conf., The Royal Academy of Engineering, London, UK, 2009.

[10] R. Simpson and A. Williams, "Application of computational fluid dynamics to the design of pico propeller turbines," in ICREDC-06, Sch. Eng., School of Engineering and Applied Sciences, University of the District of Columbia, Washington, DC, USA, 2006.

[11] I. Samora, V. Hasmatuchi, C. Münch-Alligné, M. J. Franca, A. J. Schleiss, and H. M. Ramos, "Experimental characterization of a five blade tubular propeller turbine for pipe inline installation," Journal of Renewable Energy, vol. 95, pp. 356-366, 2016.

[12] D. Thoma and C. P. Kittredge, "Centrifugal pumps operated under abnormal conditions," J. Power Sources, vol. 73, pp. 881$884,1931$.

[13] A. Williams, "Pumps as turbines for low cost micro hydro power," Journal of Renewable Energy, vol. 9, no. 1-4, pp. 12271234, 1996.

[14] "Lucid-Energy, Lucid Energy," http://www.lucidenergy.com/ wp-content/uploads/2013/08/ProductInfo_metric_July2013.pdf, (accessed April 17, 2018), 2014.

[15] J. N. Goundar, D. Prasad, and M. R. Ahmed, "Design and performance testing of a ducted savonius turbine for marine current energy extraction," in Proceedings of the ASME 2013 Int. Mech. Eng. Congr. Expo., pp. 1-6, ASME, Calif, USA, 2016.
[16] P. Khunthongjan and A. Janyalertadun, "A study of diffuser angle effect on ducted water current turbine performance using CFD," Songklanakarin Journal of Science and Technology, vol. 34, no. 1, pp. 61-67, 2012.

[17] J. Chen, H. X. Yang, C. P. Liu, C. H. Lau, and M. Lo, "A novel vertical axis water turbine for power generation from water pipelines," Energy, vol. 54, pp. 184-193, 2013.

[18] T. Ma, H. Yang, X. Guo et al., "Development of inline hydroelectric generation system from municipal water pipelines," Energy, vol. 144, pp. 535-548, 2018.

[19] P. K. Talukdar, A. Sardar, V. Kulkarni, and U. K. Saha, "Parametric analysis of model Savonius hydrokinetic turbines through experimental and computational investigations," Energy Conversion and Management, vol. 158, pp. 36-49, 2018.

[20] A. Kumar and R. P. Saini, "Performance parameters of Savonius type hydrokinetic turbine - A Review," Renewable \& Sustainable Energy Reviews, vol. 64, pp. 289-310, 2016.

[21] A. Alexander and B. Holownia, "Wind tunnel tests on a savonius rotor," Journal of Wind Engineering \& Industrial Aerodynamics, vol. 3, no. 4, pp. 343-351, 1978.

[22] W. T. Chong, A. Fazlizan, K. C. Pan, and S. C. Poh, "Design and wind tunnel testing of a Savonius wind turbine integrated with the omni-direction-guide-vane," Wref, pp. 1-7, 2012.

[23] K. Irabu and J. N. Roy, "Characteristics of wind power on Savonius rotor using a guide-box tunnel," Experimental Thermal and Fluid Science, vol. 32, no. 2, pp. 580-586, 2007.

[24] S. A. Payambarpour and A. F. Najafi, "Experimental and numerical investigations on a new developed Savonius turbine for in-pipe hydro application," Proc. Inst. Mech. Eng. Part A J. Power Energy, 2019.

[25] W. El-Askary, M. Nasef, A. AbdEL-hamid, and H. Gad, "Harvesting wind energy for improving performance of Savonius rotor," Journal of Wind Engineering \& Industrial Aerodynamics, vol. 139, pp. 8-15, 2015.

[26] B. D. Altan and M. At1lgan, "A study on increasing the performance of Savonius wind rotors," Journal of Mechanical Science and Technology, vol. 26, no. 5, pp. 1493-1499, 2012.

[27] C. Trivedi, M. J. Cervantes, and O. G. Dahlhaug, "Experimental and numerical studies of a high-head Francis turbine: a review of the Francis-99 test case," Energies, vol. 9, no. 2, pp. 1-24, 2016.

[28] K. Golecha, T. I. Eldho, and S. V. Prabhu, "Influence of the deflector plate on the performance of modified Savonius water turbine," Applied Energy, vol. 88, no. 9, pp. 3207-3217, 2011.

[29] T. G. Abu-El-Yazied, "Optimization of Wind Duct Geometry for Maximizing Power Generation of Ducted Vertical Turbines," IOSR Journal Of Engineering, vol. 4, no. 10, pp. 11-19, 2014.

[30] B. D. Altan and M. Atılgan, "An experimental and numerical study on the improvement of the performance of Savonius wind rotor," Energy Conversion and Management, vol. 49, no. 12, pp. 3425-3432, 2008.

[31] B. Wahyudi, S. Soeparman, and H. Hoeijmakers, "Optimization design of savonius diffuser blade with moving deflector for hydrokınetıc cross flow turbine rotor," Energy Procedia, vol. 68, pp. 244-253, 2015.

[32] H. Nilsson and L. Davidson, "A numerical comparison of four operating conditions in a kaplan water turbine," in Proceedings of the Focusing on Tip Clearance Flow, 20th IAHR Symp, Charlotte, USA, 2000.

[33] S. J. Kline, "Describing uncertainty in single sample experiments," Mech. Eng, vol. 7, pp. 3-8, 1953. 
[34] H. Alemi, S. A. Nourbakhsh, M. Raisee, and A. F. Najafi, "Effects of volute curvature on performance of a low specific-speed centrifugal pump at design and off-design conditions," Journal of Turbomachinery, vol. 137, no. 4, 2015, 041009.

[35] F. R. Menter, "Two-equation eddy-viscosity turbulence models for engineering applications," AIAA Journal, vol. 32, no. 8, pp. 1598-1605, 1994.

[36] F. R. Menter and T. Esch, "Elements of industrial heat transfer predictions," in Proceedings of the 16th Brazilian Congr. Mech. Eng., pp. 117-127, 2001.

[37] F. Menter, "Zonal two equation k-w turbulence models for aerodynamic flows," in Proceedings of the 23rd Fluid Dyn. Plasmadynamics, Lasers Conf., 1993.

[38] D. C. Wilcox, Turbulence Modeling for CFD, DCW industries La Canada, CA, USA, 1998.

[39] N. Kolekar and A. Banerjee, "Performance characterization and placement of a marine hydrokinetic turbine in a tidal channel under boundary proximity and blockage effects," Applied Energy, vol. 148, pp. 121-133, 2015.

[40] J. D. Anderson and J. Wendt, Computational Fluid Dynamics, Springer, 1995. 


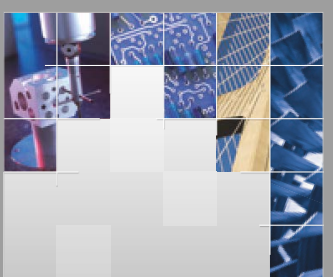

\section{Enfincering}
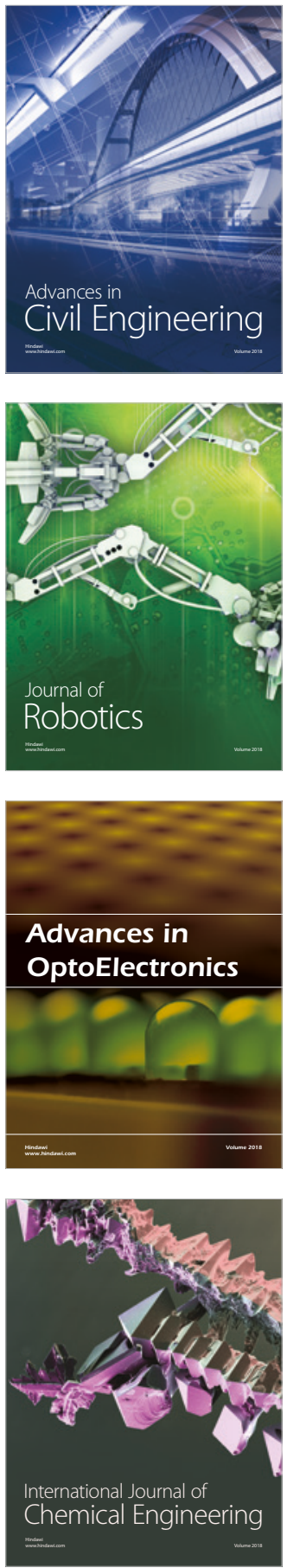

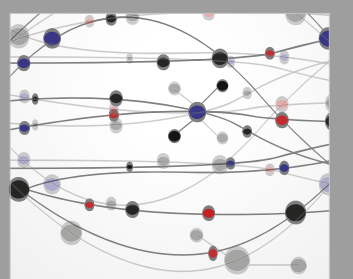

\section{Rotating \\ Machinery}

The Scientific World Journal

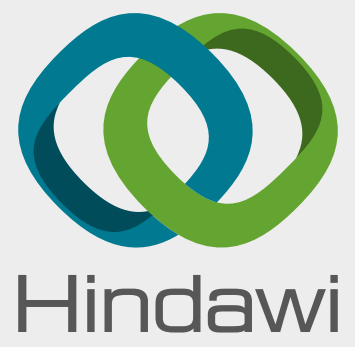

Submit your manuscripts at

www.hindawi.com
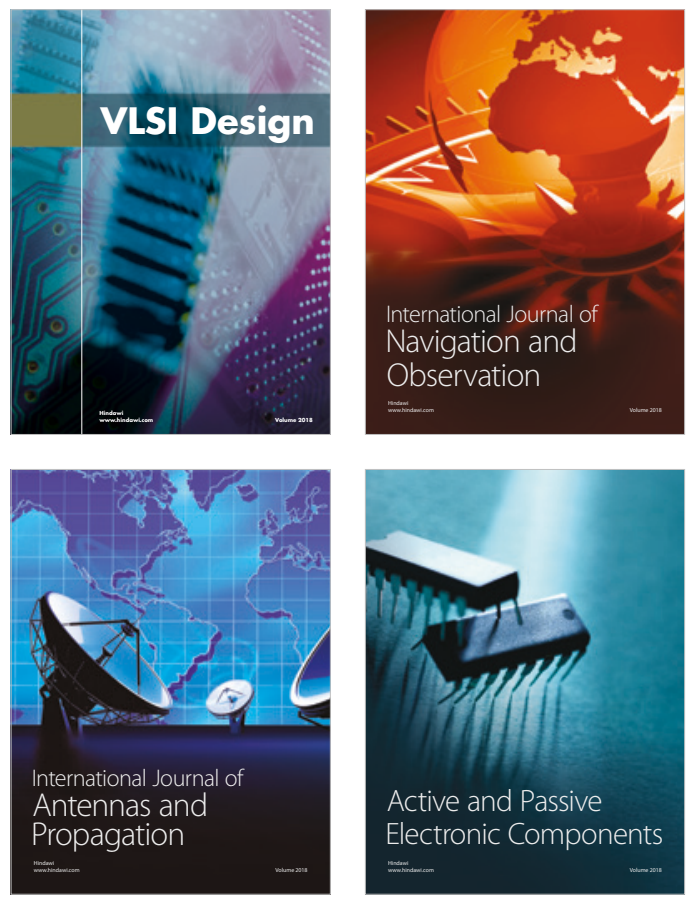
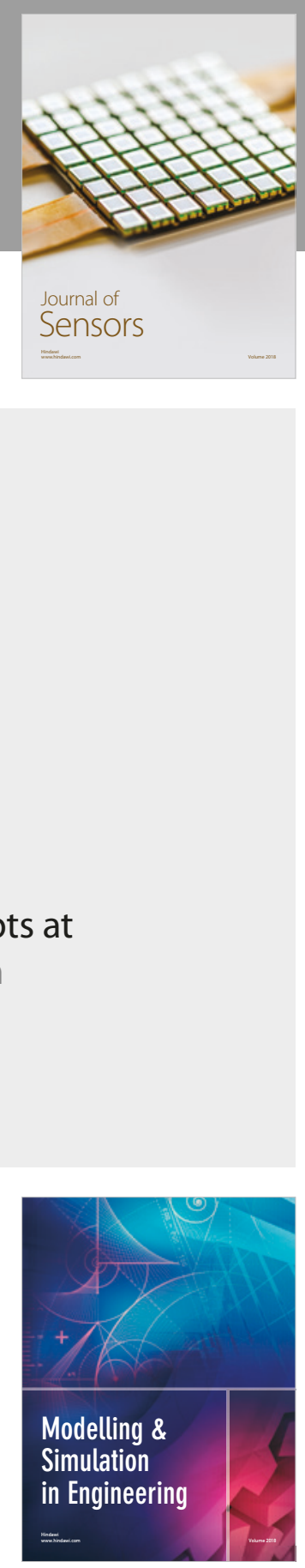

\section{Advances \\ Multimedia}
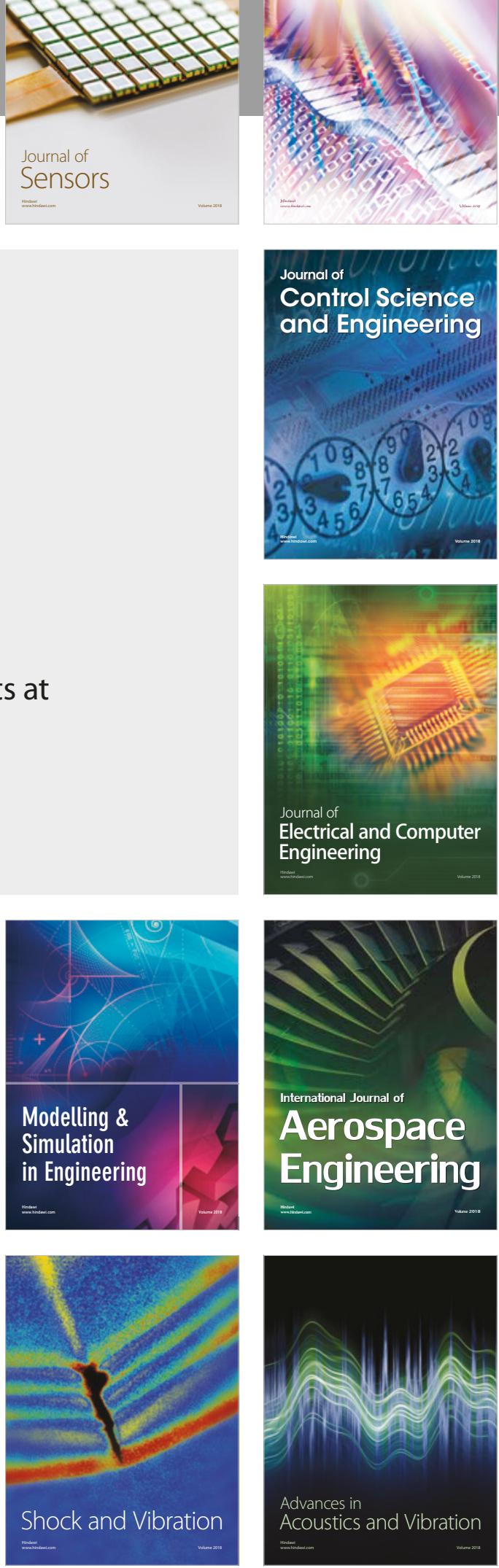